\title{
Membrane Fouling - The Enemy of Forward Osmosis
}

\author{
Z. H. Chang ${ }^{\mathrm{a}, \mathrm{b}}$, Y. H. Teow ${ }^{\mathrm{b}, \mathrm{c}}$, S. P. Yeap ${ }^{\mathrm{a}} \&$ J. Y. Sum ${ }^{\mathrm{a} *}$ \\ aDepartment of Petroleum and Chemical Engineering, Faculty of Engineering, \\ Technology and Built Environment, UCSI University, 56000 Cheras, \\ Kuala Lumpur, Malaysia \\ ${ }^{b}$ Department of Chemical and Process Engineering, Faculty of Engineering and Built \\ Environment, Universiti Kebangsaan Malaysia, 43600 Bangi, \\ Selangor Darul Ehsan, Malaysia \\ ${ }^{c}$ Research Centre for Sustainable Process Technology (CESPRO), Faculty of \\ Engineering and Built Environment, Universiti Kebangsaan Malaysia, 43600 Bangi, \\ Selangor Darul Ehsan, Malaysia
}

Submitted: 6/5/2021. Revised edition: 8/6/2021. Accepted: 8/6/2021. Available online: 15/7/2021

\begin{abstract}
Forward osmosis (FO) is an osmotically driven membrane separation process. It is potentially applied in various industries for nutrient recovery and water reclamation. Although FO showed a lesser fouling tendency than other pressure-driven membrane processes, the solutes in the feed solution would still deposit on the membrane surface, forming a fouling layer that resists water permeation. For that reason, fouling mitigation is a trending issue in the FO process. A better understanding of the fouling mechanism is required before opting for the appropriate strategy to mitigate it. This article describes the fouling mechanism based on different foulant presented in the feed, followed by a method in relieving fouling in the FO process.
\end{abstract}

Keywords: Fouling, forward osmosis, fouling mechanism, fouling mitigation, membrane cleaning

\subsection{INTRODUCTION}

Forward osmosis (FO) is a membrane separation process driven by an osmotic gradient across the feed and draw sides of the membrane. According to the Scopus database, over the past five years, there have been 1,848 publications related to the FO, including article, review, and conference proceedings. As shown in Figure 1, the number of publications is steadily increased from 2017 to 2020 , showing that FO is getting much attention. The reported works mainly focus on the draw solution, fouling issue, and the fabrication and modification of membrane, as presented in Figure 2.
Numerous lab-scale studies probed the feasibility of using FO in feed dewatering and wastewater treatment. Nonetheless, the FO process has low water permeability and suffered from external fouling, limiting its application at an industry scale [1,2]. Membrane fouling is a common phenomenon observed in all classes of the membrane. It progresses through several stages, starting from the adherence of foulant on the membrane surface, followed by formation and compaction of the fouling layer. The fouling layer eventually blocks the water permeation pathway, leads to severe flux declination. Hence, this manuscript highlights the effect of fouling on the FO operation: how it 
occurs and practical strategies to minimize the impact of fouling on the filtration process.

\subsection{TYPES OF FOULANT}

Generally, the extent of membrane fouling depends on the nature of the foulant and the physicochemical properties of the membrane [3]. The adhesion strength of foulant on the membrane surface determines the regenerability of the used membrane [4]. The increase in adhesion strength will result in a more compact fouling layer that is hardly removed, thus reducing the water permeability of the membrane over time. Fortunately, the
FO membrane is experiencing lesser fouling than other pressure-driven membrane processes (e.g., MF, UF, $\mathrm{NF}$ and RF) due to the absence of hydraulic pressure [5]. Table 1 lists the common foulant found in the streams produced from various industries treated using FO. The foulant could be classified according to organic compounds, inorganic compounds, microbes, and colloids. Worth noticing that each feed stream could contain more than one type of foulant, which resulted in a complicated fouling mechanism, including organic fouling, scaling, biofouling, and colloidal fouling.

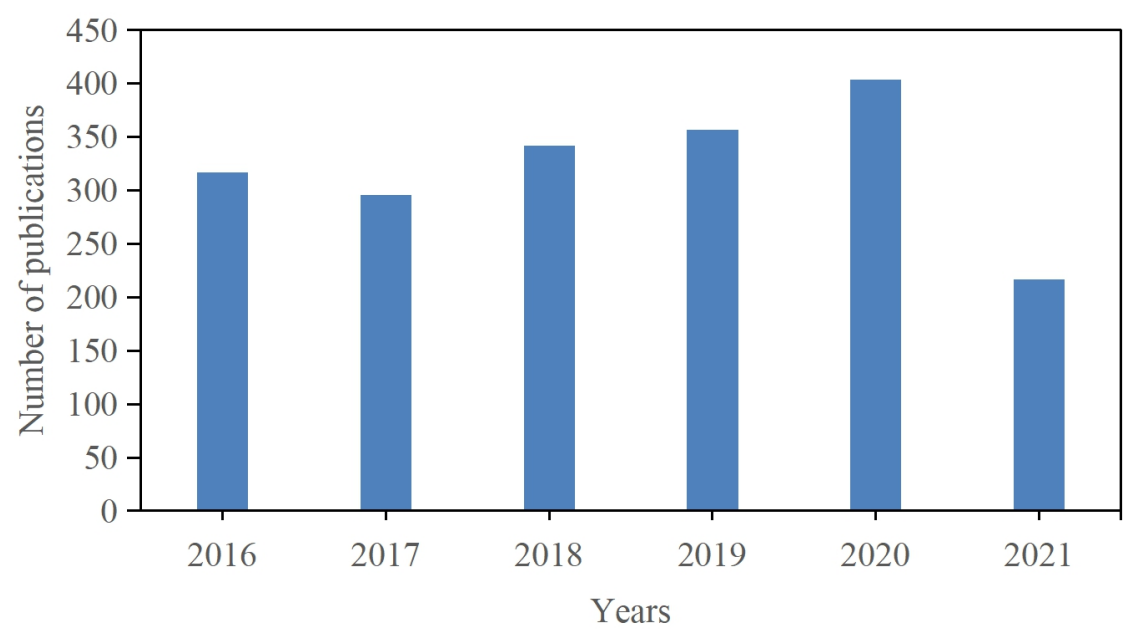

Figure 1 The total number of publications on FO from 2016 to May 2021 retrieved from the Scopus database

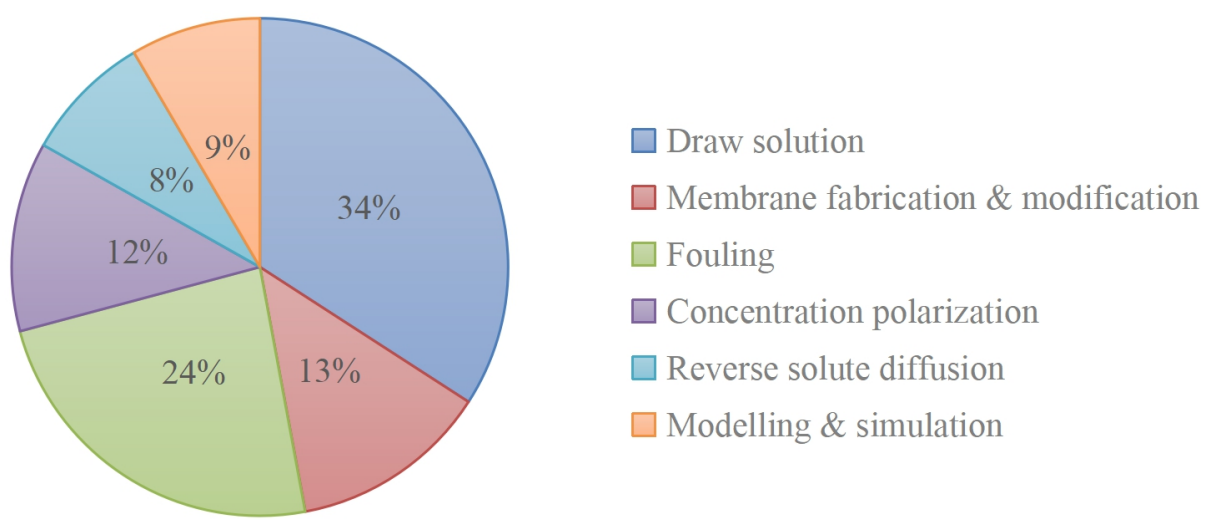

Figure 2 Research area in FO from 2016 to 2021 
Table 1 Classification of foulant from various sources of feed treated by FO

\begin{tabular}{|c|c|c|}
\hline Sources of feed & Types of foulant & Reference \\
\hline Construction water & $\begin{array}{l}\text { Inorganics (K, P, As, B, Ba, Ca, Co, Cr, } \mathrm{Cu}, \mathrm{Fe}, \mathrm{Mg} \text {, } \\
\left.\mathrm{Mn}, \mathrm{Mo}, \mathrm{Na}, \mathrm{Ni}, \mathrm{Pb}, \mathrm{Sb}, \mathrm{Se}, \mathrm{Sr}, \mathrm{V}, \mathrm{Zn}, \mathrm{SO}_{4}, \mathrm{Cl}\right)\end{array}$ & [6] \\
\hline Dairy & $\begin{array}{l}\text { Organic (proteins, lactose, fat) } \\
\text { Inorganic }(\mathrm{Na}, \mathrm{K}, \mathrm{Ca}) \\
\text { Microbes }\end{array}$ & {$[7,8]$} \\
\hline Fruit juice & $\begin{array}{l}\text { Organic (pectin, sucrose, ascorbic acids) } \\
\text { Inorganic (Ca, } \mathrm{K}, \mathrm{Mg}, \mathrm{Na}, \mathrm{P})\end{array}$ & [9] \\
\hline Microalga biofuel & $\begin{array}{l}\text { Microbes (microalgal cells) } \\
\text { Organic (algogenic organic matter) }\end{array}$ & {$[10]$} \\
\hline Mining & $\begin{array}{l}\text { Organic (naphthenic acids, oily substances) } \\
\text { Inorganic (heavy metals) }\end{array}$ & {$[11,12]$} \\
\hline $\begin{array}{l}\text { Municipal } \\
\text { wastewater }\end{array}$ & $\begin{array}{l}\text { Organic (polysaccharide, humic acid, protein, } \\
\text { pharmaceuticals, sodium dodecyl sulphate, sodium } \\
\text { alginate) } \\
\text { Inorganic }\left(\mathrm{K}, \mathrm{Ca}, \mathrm{Mg}, \mathrm{Si}, \mathrm{Al}, \mathrm{SO}_{4}, \mathrm{PO}_{4}\right)\end{array}$ & [13-15] \\
\hline Oil/gas recovery & $\begin{array}{l}\text { Organic (polycyclic aromatic hydrocarbon (PAHs), } \\
\text { oily substances, humic-like organic compounds, } \\
\text { fulvic-like organic compounds) } \\
\text { Inorganic ( } \mathrm{F}, \mathrm{Cl}, \mathrm{Br}, \mathrm{Ca}, \mathrm{Mg}, \mathrm{K}, \mathrm{Na}, \mathrm{Fe}, \mathrm{Sr} \text { ) } \\
\text { Colloidal (Silica) }\end{array}$ & {$[16]$} \\
\hline $\begin{array}{l}\text { Radioactive power } \\
\text { plant }\end{array}$ & $\begin{array}{l}\text { Organic (proteins) } \\
\text { Inorganics (radionuclides: }{ }^{90} \mathrm{Y},{ }^{125} \mathrm{I},{ }^{131} \mathrm{I},{ }^{89} \mathrm{Sr},{ }^{192} \mathrm{Ir} \text {, } \\
{ }^{60} \mathrm{Co} \text {, and }{ }^{137} \mathrm{Cs} \text { ) }\end{array}$ & {$[17]$} \\
\hline Textile & $\begin{array}{l}\text { Organic (Dyes, acetic acid) } \\
\text { Inorganic (Dyes, } \mathrm{Mg}, \mathrm{Na}, \mathrm{Ca}, \mathrm{SO}_{4}, \mathrm{Cl}, \mathrm{PO}_{4} \text { ) }\end{array}$ & [18] \\
\hline
\end{tabular}

\subsection{Organic Foulants}

Organic compounds could be presented as natural organic matter and synthetic organic compounds [19]. The organic foulant adsorbs on the membrane surface, then gradually develops into a thick and dense cake layer driven by intermolecular Van der Waals forces, hydrogen bonding, and electrostatic interactions [20]. Besides, the presence of the organic fouling layer would alter the membrane surface roughness, hydrophilicity, and charge [21, 22]. Most articles reported alginate, bovine serum albumin (BSA) and humic substances as model foulant used to assess the antifouling properties of the FO membrane [20, 21, 23]. Despite the high retention of solutes from the feed, the FO suffered from fouling due to the accumulation of retained solute on the membrane surface. Most of the abovementioned works claimed that organic fouling is reversible. Simple backwashing could remove the fouling layer, and the membrane could be restored to its initial condition. However, the fouling could be irreversible when the existing 
ions/molecules in the feed has great affinity towards the foulant. For instance, sodium dodecyl sulfate (SDS) in the feed could be bridged to the membrane surface that has been fouled with humic substances via hydrophobic interaction [15]. An irreversible fouling layer could be formed between humic substances, low molecular weight organics and building block [24]. The small foulant complexes were trapped and deposited on a rough membrane surface, which could not be cleaned thoroughly.

Oil is a hydrophobic organic foulant found in oily wastewater such as produced water and palm oil mill effluent digestate $[25,26]$. Huang et al. [12] and Ahmad et al. [27] explained how the oil droplet fouls the membrane. It started with wetting of membrane surface and pore, followed by adsorption on membrane surface due to hydrophobic interaction and pore blockage [28]. On top of that, Ge et al. [29] claimed that the size of an oil droplet in emulsion could determine the extent of membrane fouling, as smaller droplet can be trapped easily in the membrane pores. Tremendous works had been reported on using FO in treating oily wastewater [30]. Unavoidable flux declination due to fouling was observed. Yet, the fouling was claimed reversible; it can be removed through a post-filtration cleaning process using a chemical cleaning agent such as SDS [31]. The SDS forms micelle that surrounds the foulant, enhancing the wettability of foulants; hence the fouling layer could be easily removed under high-speed crossflow.

\subsection{Inorganic Foulants}

Inorganic compounds such as silica, calcium and magnesium salts are the foulants commonly found in wastewater, seawater and brackish water [32, 33]. These inorganic compounds induce the membrane fouling/scaling through surface crystallization and crystal deposition [23]. The former describes the adsorption of inorganic salt ions on the membrane surface, followed by the nucleation and growth of the salt crystals. On the contrary, crystal deposition occurs after salt crystals are formed in the bulk solution. Both mechanisms produce a thick, dense scale on the membrane surface, resulting in severe flux declination.

The abovementioned fouling is caused by the inorganic compounds present in the feed solution. However, Li et al. [34] found that scaling could also happen when the anions reversely diffused from the draw solution interacting with the cations present in the feed solution, resulting in the formation of insoluble crystal penetrating through the membrane layer. The membrane under this condition experiences dramatic flux declination and is hardly regenerated through hydraulic cleaning.

\subsection{Microbes}

FO process was used to dewatering activated sludge, microalga biofuel, and hybridization with membrane bioreactor [10, 35, 36]. Unfortunately, the membranes experiencing different extent of flux declination due to membrane fouling and external concentration polarization. Bacterial cells and algae are the two major microbial foulants that lead to biofouling [10, 32]. Microbes are deposited on the membrane surface, followed by biofilm formation in a non-sterile and nutritious environment $[23,37]$. This biofilm has a loose multilayered structure, consisting of live and dead bacterial cells reinforced by the gel-like self-produced extracellular polymeric substances. 
The initial stage of biofouling driven by Van der Waals forces is reversible. Water permeation flux in this stage remains unaffected [38]. However, the flux has deteriorated when the biofilm grows in the later stage. The biofilm is hardly removed due to firm bacterial adhesion protection provided by the extracellular polymeric substances [23].

Other than the extracellular polymeric substances, recently, transparent exopolymer particles are also recognised as the primary sources of biofouling [39]. These particles are usually found in freshwater, wastewater and marine water heavily colonized by microorganisms [40, 41]. Berman et al. [42] claimed that most of the extracellular polymeric substances present in the feedwater originated from these transparent exopolymer particles. Meng et al. [39] highlighted the biofouling caused by transparent exopolymer particles was more significant than the independent bacteria. The membrane experienced a greater flux declination in the presence of transparent exopolymer particles.

\subsection{Colloids}

Colloids are defined as negatively charged particles with a size range between 1-1000 nm [23, 32]. The typical colloids present in the water include silica, clay, rust and biocolloids such as bacteria and viruses. The deposition of colloids on the membrane surface forms a colloidal fouling layer. This fouling layer further induces cake layer hydraulic resistance and cake-enhanced osmotic pressure (CEOP), with the latter has a greater impact on water flux declination. Besides, the colloidal fouling layer will induce cake-enhanced concentration polarization (CECP) that promotes salt diffusion across the membrane [43].

As mentioned in Section 2.2, silica is considered an inorganic foulant. However, Lai et al. [44] claimed that silica is also a potential foulant for colloidal fouling depending on its fouling mechanism. Colloidal silica fouling is caused by the deposition of silica particles on the membrane, while silica scaling is caused by the surface polymerization of silicic acids [45]. They further reported that the effect of colloidal silica fouling is less severe than silica scaling, indicated that both CECP and CEOP caused by the colloidal fouling are less significant in affecting the FO performance [44].

\subsection{Combined Foulants}

The previous section discusses the impact of every single type of foulant on the FO process. In fact, various types of foulant could be co-existing in a real industrial effluent [23]. There will be intermolecular interaction between the foulant and the foulant with the membrane surface, making the fouling mechanism complex [19, $46,47]$. One typical example of combined fouling is the co-existing of the divalent cations (e.g., $\mathrm{Ca}^{2+}$ and $\mathrm{Mg}^{2+}$ ions) and the organic compounds. These cations could worsen the degree of fouling by chelating with the carboxylic groups in the organic compounds, resulting in the formation of a compact, dense and heavily crosslinked fouled layer [3, 4, 48]. Besides, wastewater effluent from microbial fuel cell contains microbe and inorganic substances, making the FO membrane experiencing inorganic and biofouling simultaneously [49]. Lee et al. [17] probed the feasibility of FO in treating radioactive wastewater that contains a mixture of organic (protein) and inorganic substances (radionuclides). They found that the fouling layer is recalcitrant, and a hydraulic washing is insufficient to recover the membrane back to its initial state. 


\subsection{STRATEGIES TO MITIGATE FOULING}

Membrane fouling cannot be eliminated, yet there are solutions to mitigate it. As shown in Figure 3, this section introduces the approaches used to minimise fouling in a FO process, including the pretreatment of the feed solution, selection of membrane, manipulation of process variables and post-filtration membrane cleaning.

\subsection{Pretreatment of Feed Solution}

Pretreatment of the feed solution is necessary to reduce the amount of foulant, hence, decreasing the fouling tendency and prolonging the membrane service life. A physical pretreatment such as centrifugation [9], sedimentation [6], filtration [6], electro-coagulation [50], and irradiation [24] is suitable for the removal of suspended particles from the feed. A pretreatment based on sedimentation or centrifugation is recommended for a fruit juice concentrating process [9]. The potential foulant such as pectin and fruits pulps are removed, thus reducing the organic fouling tendency. Electrocoagulation is proven effective in reducing amount of oil and grease in the produced water [50]. A settling and filtration setup was used to pretreat the construction water before the dewatering process using FO [5]. Large size particles are gravitationally settled down, while the suspended particles were removed in subsequent multimedia filtration. As a result, the colloidal fouling was minimized and the permeate flux was enhanced.

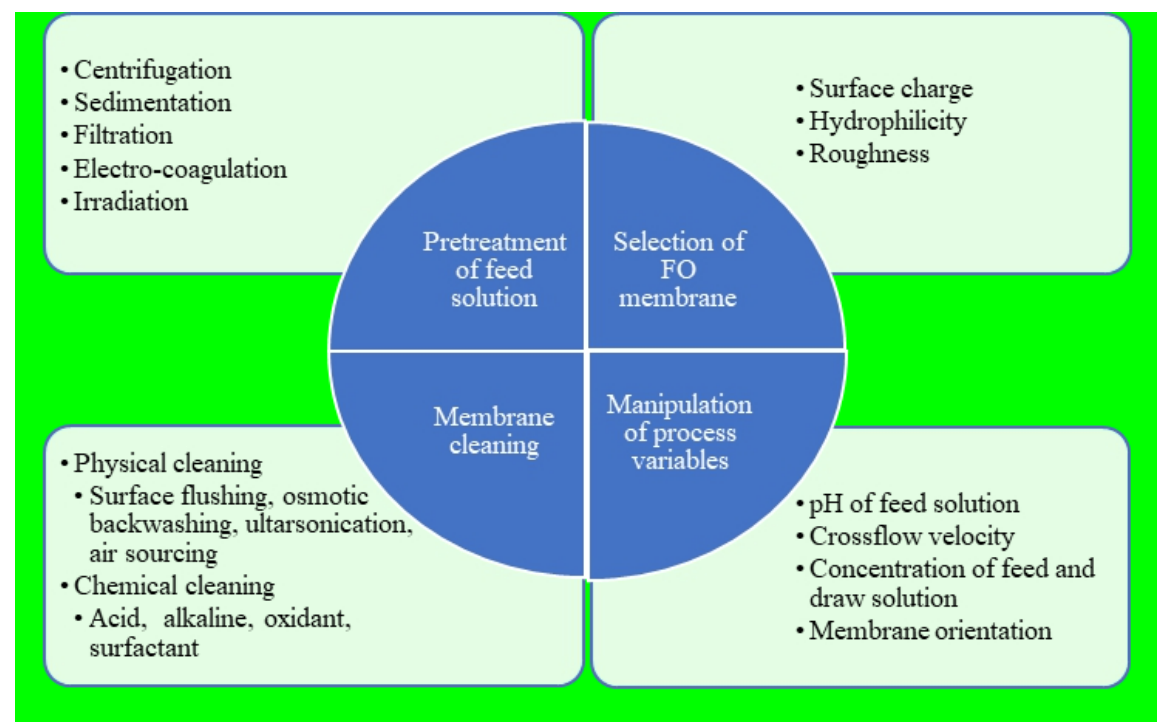

Figure 3 Summary of the fouling mitigation methods

On the contrary, chemical pretreatment involves the use of chemical additives to remove the foulant from the feed via coagulation [51], oxidation [24] and chlorination [52]. Coagulant such as aluminium chloride and sodium aluminate could remove phosphate from calcium phosphate-rich wastewater [51]. A reduction of biofouling potential could be made through disinfection using chloramine [52]. The chloramine inhibits the growth of intact bacterial cells, which further prevents biofilm formation over the membrane surface. Chlorine could be another disinfectant; 
however, it damages the membrane structure and deteriorates FO performance over time [32]. In an oxidation process, a large molecular weight hydrophobic compound is degraded into smaller hydrophilic segments [24]. Thus, fewer organic compounds could be adsorbed onto the membrane surface.

\subsection{Selection of FO Membrane}

The physicochemical properties of the membrane, in terms of surface charge, hydrophilicity and roughness, are critical in determining the extent of fouling. Understanding the nature of the foulants and their interaction with the membrane surface is necessary before selecting a suitable membrane for the FO process. There are a few considerations that make the membrane resists fouling. First, the membrane surface should be smooth to prevent the entrapment of foulant $[2$, $53,54]$. A porous membrane with a rough ridge and valley surface can easily trap the foulant, making the cleaning inefficient. It is also desired that the foulant and membrane surface possess the same sign of charge for enhancive electrostatic repulsion. Most of the organic and colloidal particles are negatively charged in nature [32, 55]. By having a negatively charged membrane surface, those foulants could be electrostatically repelled. A neutral membrane is favoured for a feed containing a mixture of both positively and negatively charged foulants [32]. Lastly, an excellent antifoul FO membrane should exhibit good water wettability. A hydrophilic membrane will attract water to form a hydration layer over its surface [32]. The hydration layer acts as a barrier to prevent the direct deposition of foulants on the membrane.

A pristine $\mathrm{FO}$ membrane may still be experiencing fouling. The membrane could be functionalized to reduce the fouling tendency. The incorporation of hydrophilic nanofillers, for instance, graphene oxide (GO) [56] and titanium oxide $\left(\mathrm{TiO}_{2}\right)$ [57], significantly improves the membrane hydrophilicity and subsequently, the antifouling properties of the membrane. Grafting the membrane with silver-based metalorganic frameworks improves the membrane resistivity towards microbial growth [58]. The membrane surface could also be modified using polydopamine (PDA) [59]. It was found that the introduction of dopamine brings more hydrophilic functional groups and make the membrane more negatively charged, resulting in a better scaling resistance.

\subsection{Manipulation of Filtration Process Variables}

Manipulation of variables in the FO process could be the most economical yet feasible approach in controlling the fouling. Few variables are identified, and how they play roles in fouling mitigation is discussed. It is known that both ionic foulants and membrane surface charge could be $\mathrm{pH}$-dependent. Thus, the $\mathrm{pH}$ of the feed solution could be adjusted to intensify the electrostatic repulsion between the foulants and the membrane surface. For example, given a negatively charged FO membrane, the $\mathrm{pH}$ of the solution should be adjusted to above the isoelectric point of the solutes/foulant [60]. In this $\mathrm{pH}$ range, the solutes are negatively charged. Hence, they will be repelled from the co-ionic membrane surface. In the meantime, a low $\mathrm{pH}$ range $(\mathrm{pH} \leq 4)$ should be avoided for the feed containing organic compounds, such as humic substances, octanoic acids and BSA [53, 60-62]. The proton $\left(\mathrm{H}^{+}\right)$ would interact with the functional 
groups present on the organic compounds (e.g., carboxylic groups), leading to solute aggregations and deposition on the membrane surface, forming a sparse, thick and porous fouling layer. On the other hand, a high $\mathrm{pH}$ range $(\mathrm{pH} \geq 8)$ makes the organic compounds ionic and thus more soluble in the solution $[53,62]$. Not to mention, there will still be some small organic solutes that could penetrate deep into the membrane matrix and block its internal pores.

The crossflow velocity of both feed and draw sides could influence the extent of membrane fouling. High crossflow velocity induces shear force over the membrane surface to wash off the deposited cake layer. In contrast, a lower flow rate would hydrodynamically drag the foulants towards the membrane surface and causing membrane fouling $[15,53]$. On the other hand, a feed with a high concentration promotes the foulantfoulant and foulant-membrane interaction [7]. The solutes in the solution tend to aggregate and adsorbed onto the membrane surface. Though a high concentration draw solution possesses high withdrawal ability, yet it triggers membrane fouling [53]. The fouling could be linked to a higher rate of reverse solute flux. The membrane orientation, either AL-FS or AL-DS, is decided based on the composition of the feed solution [2]. AL-FS mode is suitable for feed solution with high fouling potential, while AL-DS mode is more applicable in treating feed solution with lower fouling tendency. The accumulation of foulants in the pores is favoured since the substrate possesses relatively large pores than that of the selective layer.

\subsection{Membrane Cleaning}

A cleaning process is conducted to restore the exhausted membrane and thus prolong the membrane service life. Cleaning for fouled FO membrane would be easier than a pressure-driven membrane illustrated in Figure 4. The cleaning can be done physically, chemically or a combination of both. In a physical cleaning process, the fouling layer is removed from the membrane surface via direct/surface flushing, osmotic backwashing, ultrasonication, and air sourcing [3, 4, $8,43,63]$. Surface flushing is the most used technique, whereby the fouling layer is sheared from the membrane surface due to the high-speed crossflow of the cleaning agent. It works well in removing biofouling and organic fouling induced by protein, alginate and humic substances [8, 63]. Osmotic backwashing tackles the compacted scale and the foulants accumulated in the membrane pores $[43,53,63]$. It works based on the reverse water flux generated by the osmotic gradient between two salinity solutions [63]. Some reports revealed that a combination technique is necessary to improve the cleaning efficiency further. For instance, a combination of ultrasound and flushing has been reported in regenerating the membrane after dewatering activated sludge [64]; air sourcing combined with hydraulic flushing to remove the silica scale layer [4].

The removal could be challenging if the foulants firmly adhered to the membrane surface. Chemical cleaning could weaken the bonding between the foulant and the membrane surface [2, 19]. The added chemical alters the properties of foulants, make them more water-soluble and hence easily flushed away [55]. An acidic solution could release inorganic fouling, while an alkali solution effectively removes organic fouling [65]. However, membrane structure can be altered in alkali conditions, affecting the FO performance [15]. Other cleaning 
agents such as oxidant, surfactant, and complexant have been reported for cleaning purposes $[47,66]$. A combined physical/chemical cleaning is recommended to remove the foulants stuck inside the membrane pores [19]. This method involves backwashing and chemicals dosage to cleave the bonds between foulants and membrane surface. Liu et al. [67] conducted a series of on-line and external cleaning to remove the deposition of radionuclides on FO membrane after the treatment of radioactive wastewater. Most foulants are released during the on-line cleaning using deionized water, resulting in an enhancement of water flux to $69 \%$. An additional two-step external cleaning method (chemical cleaning using hydrochloric acid followed by ultrasound) further remove the radionuclides fouled on the membrane.
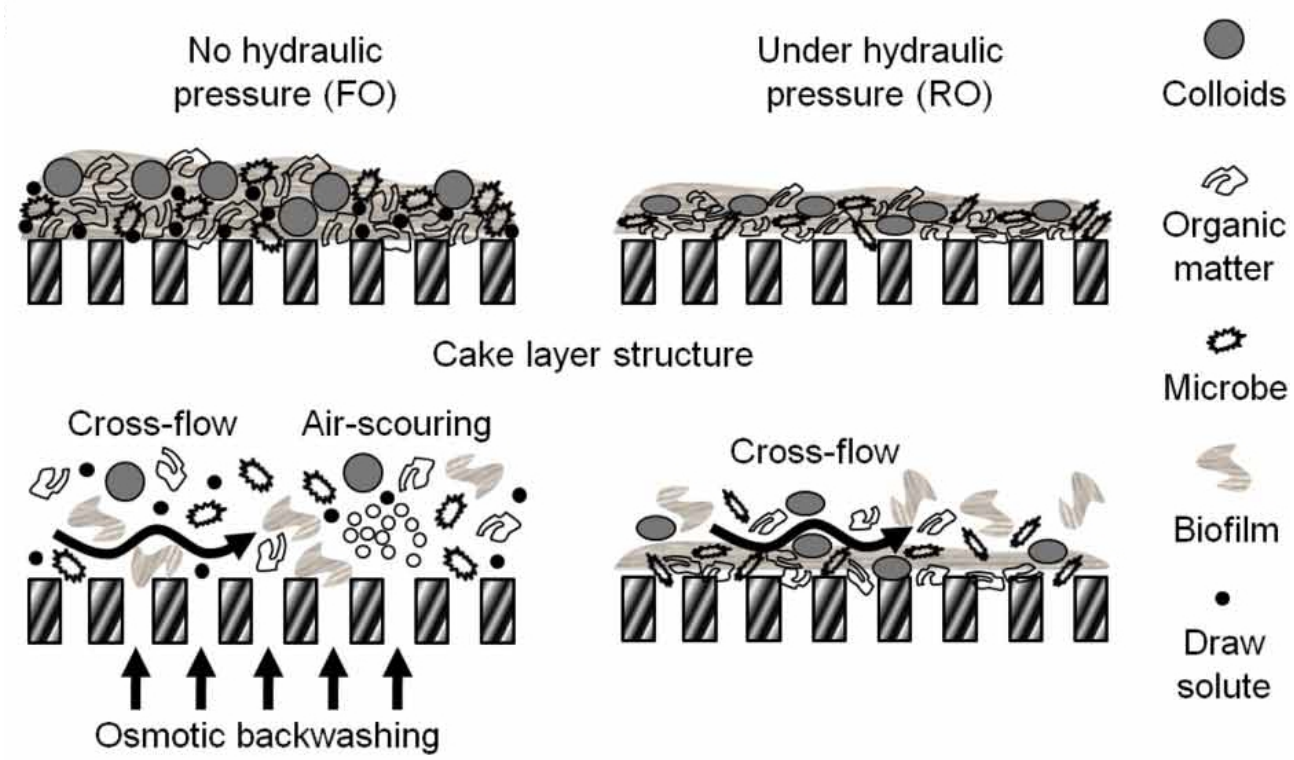

Physical cleaning

Figure 4 Illustration of fouling layer during physical cleaning in FO and RO [46]

\subsection{CONCLUSION AND FUTURE OUTLOOK}

Tremendous research works have been conducted to exploit the potential of the FO process. Unfortunately, membrane fouling is still significant in FO that limits it to be widely applied in industry. Fouling is unavoidable. Understanding the fouling mechanism is crucial before selecting the membrane materials and deciding the appropriate strategies to mitigate fouling. Current research is mainly studying the fouling phenomenon based on a single model foulant. The outcome of the studies may not reflect the complexity of the real industrial effluent. Hence, there is an urgent need to study the fouling phenomenon using real/synthetic industrial effluent, followed by postulating a mechanism to describe the fouling in a complex mixture. The next stage should focus on how to preserve the FO membrane. A single-stage cleaning system may not be adequate to regenerate the membrane suffering from a combined fouling mechanism. A hybrid cleaning system is necessary to improve the 
regeneration efficiency and hence prolong the service life of the membrane.

\section{ACKNOWLEDGEMENT}

The authors gratefully acknowledge CERVIE, UCSI University and research grant REIG-FETBE-2020/022 for the financial support.

\section{REFERENCES}

[1] L. Li, W. Shi, S. Yu. 2020. Research on Forward Osmosis Membrane Technology Still Needs Improvement in Water Recovery and Wastewater Treatment. Water (Switzerland). 12: 1-27. https://doi.org/10.3390/w12010 107.

[2] J. Wang, X. Liu. 2021. Forward Osmosis Technology for Water Treatment: Recent Advances and Future Perspectives. $J$. Clean. Prod. 280: 124354. https://doi.org/10.1016/j.jclepro. 2020.124354.

[3] M. Khraisheh, M. Gulied, F. Almomani. 2020. Effect of membrane fouling on fertilizerDrawn Forward Osmosis Desalination Performance. Membranes (Basel). 10: 1-16. https://doi.org/10.3390/membra nes10090243.

[4] Y. Kim, S. Li, N. Ghaffour. 2020. Evaluation of Different Cleaning Strategies for Different Types of Forward Osmosis Membrane Fouling and Scaling. J. Memb. Sci. 596: 117731. https://doi.org/10.1016/j.memsci. 2019.117731 .

[5] F. A. Siddiqui, Q. She, A. G. Fane, R. W. Field. 2018. Exploring the Differences
Between Forward Osmosis and Reverse Osmosis Fouling. $J$. Memb. Sci. 565: 241-253. https://doi.org/10.1016/j.memsci. 2018.08.034.

[6] A. H. Hawari, A. Al-Qahoumi, A. Ltaief, S. Zaidi, A. Altaee. 2018. Dilution of Seawater Using Dewatered Construction Water in a Hybrid Forward Osmosis System. J. Clean. Prod. 195: 365-373. https://doi.org/10.1016/j.jclepro. 2018.05.211.

[7] W. Q. Wang, Y. C. Wa, X. F. Zhang, R. X. Gu, M. L. Lu. 2019. Whey Protein Membrane Processing Methods and Membrane Fouling Mechanism Analysis. Food Chem. 289: 468481.

https://doi.org/10.1016/j.foodch em.2019.03.086.

[8] Y. N. Wang, R. Wang, W. Li, C. Y. Tang. 2017. Whey recovery Using Forward Osmosis Evaluating the Factors Limiting the Flux Performance. J. Memb. Sci. 533: 179-189. https://doi.org/10.1016/j.memsci. 2017.03.047.

[9] D. I. Kim, G. Gwak, M. Zhan, S. Hong. 2019. Sustainable Dewatering of Grapefruit Juice Through Forward Osmosis: Improving Membrane Performance, Fouling Control, and Product Quality. J. Memb. Sci. 578: 53-60. https://doi.org/10.1016/j.memsci. 2019.02.031.

[10] J. Ye, Q. Zhou, X. Zhang, Q. Hu. 2018. Microalgal Dewatering Using a Polyamide Thin Film Composite Forward Osmosis Membrane and Fouling Mitigation. Algal Res. 31: 421429. https://doi.org/10.1016/j.algal.2 018.02.003. 
[11] L. Xiang, S. Zhu, M. Li, J. Zhang, M. Gamal El-Din, H. Zeng. 2019. Probing Fouling Mechanism of Naphthenic Acids on Forward Osmosis Polymer Membranes in Oil Sands Process Water Treatment. J. Memb. Sci. 576: 161-170. https://doi.org/10.1016/j.memsci. 2019.01.018.

[12] S. Huang, R. H. A. Ras, X. Tian. 2018. Antifouling Membranes for Oily Wastewater Treatment: Interplay Between Wetting and Membrane Fouling. Curr. Opin. Colloid Interface Sci. 36: 90109.

https://doi.org/10.1016/j.cocis.2 018.02.002.

[13] Y. Gao, Z. Fang, P. Liang, X. Huang. 2018. Direct Concentration of Municipal Sewage by Forward Osmosis and Membrane Fouling Behavior. Bioresour. Technol. 247: 730-735. https://doi.org/10.1016/j.biortec h.2017.09.145.

[14] S. Kim, K. H. Chu, Y. A. J. AlHamadani, C. M. Park, M. Jang, D. H. Kim, et al. 2018. Removal of Contaminants of Emerging Concern by Membranes in Water and Wastewater: A Review. Chem. Eng. J. 335: 896-914.

https://doi.org/10.1016/j.cej.201 7.11.044.

[15] C. Wang, M. Wang, Y. Li. 2020. Effects of Sodium Dodecyl Sulfate on Forward Osmosis Membrane Fouling and Its Cleaning. Chemosphere. 257: 127180.

https://doi.org/10.1016/j.chemos phere.2020.127180.

[16] B. D. Coday, N. Almaraz, T. Y. Cath. 2015. Forward Osmosis Desalination of Oil and Gas Wastewater: Impacts of
Membrane Selection and Operating Conditions on Process Performance. J. Memb. Sci. 488: 40-55. https://doi.org/10.1016/j.memsci. 2015.03.059.

[17] S. Lee, Y. Kim, J. Park, H. K. Shon, S. Hong. 2018. Treatment of Medical Radioactive Liquid Waste Using Forward Osmosis (FO) Membrane Process. $J$. Memb. Sci. 556: 238-247. https://doi.org/10.1016/j.memsci. 2018.04.008.

[18] G. Han, C.Z. Liang, T. S. Chung, M. Weber, C. Staudt, C. Maletzko. 2016. Combination of Forward Osmosis (FO) Process with Coagulation/flocculation (CF) for Potential Treatment Of Textile Wastewater. Water Res. 91: 361-370. https://doi.org/10.1016/j.watres. 2016.01.031.

[19] S. Yadav, I. Ibrar, S. Bakly, D. Khanafer, A. Altaee, V. C. Padmanaban, et al. 2020. Organic Fouling in Forward Osmosis: A Comprehensive Review. Water (Switzerland). 12: 1505.

https://doi.org/10.3390/w12051 505.

[20] M. He, L. Wang, Y. Lv, X. Wang, Z. Zhang, Q. Cui, et al. 2020. Effect of a Novel Hydrophilic Double-skinned Support Layer on Improving Anti-fouling Performance of Thin-film Composite Forward Osmosis Membrane. Colloids Surfaces A Physicochem. Eng. Asp. $\quad$ 602: 125081. https://doi.org/10.1016/j.colsurf a.2020.125081.

[21] N. M. Mazlan, P. Marchetti, H. A. Maples, B. Gu, S. Karan, A. Bismarck, et al. 2016. Organic Fouling Behaviour of Structurally and Chemically 
Different Forward Osmosis Membranes - A Study of Cellulose Triacetate and Thin Film Composite Membranes. $J$. Memb. Sci. 520: 247-261. https://doi.org/10.1016/j.memsci. 2016.07.065.

[22] C. Li, H. Li, Y. Yang, L. A. Hou. 2020. Removal of Pharmaceuticals by Fouled Forward Osmosis Membranes: Impact of DOM Fractions, $\mathrm{Ca}(2+)$ and Real Water. Sci Total Env. 738: 139757. https://doi.org/10.1016/j.scitoten v.2020.139757.

[23] L. Li, X.P. Liu, H. Q. Li. 2017. A Review of Forward Osmosis Membrane Fouling: Types, Research Methods and Future Prospects. Environ. Technol. Rev. 6: 26-46. https://doi.org/10.1080/2162251 5.2016.1278277.

[24] B. K. Pramanik, F. I. Hai, F. A. Roddick. 2019. Ultraviolet/persulfate Pretreatment for Organic Fouling Mitigation of Forward Osmosis Membrane: Possible Application in Nutrient Mining From Dairy Wastewater. Sep. Purif. Technol. 217: 215-220. https://doi.org/10.1016/j.seppur. 2019.02.016.

[25] D. Johnson, A. W. Lun, A. W. Mohammed, N. Hilal. 2020. Dewatering of POME Digestate Using Lignosulfonate Driven Forward Osmosis. Sep. Purif. Technol. 235: 116151. https://doi.org/https://doi.org/10. 1016/j.seppur.2019.116151.

[26] W. N. A. S. Abdullah, W. J. Lau, F. Aziz, D. Emadzadeh, A. F. Ismail. 2018. Performance of Nanofiltration-Like ForwardOsmosis Membranes for Aerobically Treated Palm Oil Mill Effluent. Chem. Eng.
Technol. 41: 303-312. https://doi.org/https://doi.org/10. 1002/ceat.201700339.

[27] N. A. Ahmad, P. S. Goh, Z. A. Karim, A. F. Ismail. 2018. Thin Film Composite Membrane for Oily Waste Water Treatment: Recent Advances and Challenges. Membranes (Basel). 8: 86. https://doi.org/10.3390/membra nes8040086.

[28] Y. X. Huang, Z. Wang, J. Jin, S. Lin. 2017. Novel Janus Membrane for Membrane Distillation with Simultaneous Fouling and Wetting Resistance. Environ. Sci. Technol. 51: 13304-13310.

https://doi.org/10.1021/acs.est.7 b02848.

[29] Q. Ge, G. L. Amy, T. S. Chung. 2017. Forward Osmosis for Oily Wastewater Reclamation: MultiCharged Oxalic Acid Complexes as Draw Solutes. Water Res. 122: 580-590. https://doi.org/10.1016/j.watres. 2017.06.025.

[30] C. S. Ong, B. Al-Anzi, W. J. Lau, P. S. Goh, G. S. Lai, A. F. Ismail, et al. 2017. Anti-Fouling Double-Skinned Forward Osmosis Membrane with Zwitterionic Brush for Oily Wastewater Treatment. Sci. Rep. 7: $1-11$. https://doi.org/10.1038/s41598017-07369-4.

[31] S. Zhao, J. Minier-Matar, S. Chou, R. Wang, A. G. Fane, S. Adham. 2017. Gas Field Produced/Process Water Treatment Using Forward Osmosis Hollow Fiber Membrane: Membrane Fouling and Chemical Cleaning. Desalination. 402: 143-151. https://doi.org/https://doi.org/10. 1016/j.desal.2016.10.006. 
[32] I. Ibrar, O. Naji, A. Sharif, A. Malekizadeh, A. Alhawari, A. A. Alanezi, et al. 2019. A Review of Fouling Mechanisms, Control Strategies and Real-Time Fouling Monitoring Techniques in Forward Osmosis. Water (Switzerland). $\quad 11$ : 695. https://doi.org/10.3390/w11040 695.

[33] M. Xie, S. R. Gray. 2016. Gypsum Scaling in Forward Osmosis: Role of Membrane Surface Chemistry. J. Memb. Sci. 513: 250-259. https://doi.org/10.1016/j.memsci. 2016.04.022.

[34] Z. Li, R. Valladares Linares, S. Bucs, C. Aubry, N. Ghaffour, J.S. Vrouwenvelder, et al. 2015. Calcium Carbonate Scaling in Seawater Desalination by Ammonia-carbon Dioxide Forward Osmosis: Mechanism and Implications. J. Memb. Sci. 481: 36-43. https://doi.org/10.1016/j.memsci. 2014.12.055.

[35] S. S. Bucs, R. Valladares Linares, J. S. Vrouwenvelder, C. Picioreanu. 2016. Biofouling in Forward Osmosis Systems: An Experimental and Numerical Study. Water Res. 106: 86-97. https://doi.org/10.1016/j.watres. 2016.09.031.

[36] Q. Zhang, Y. W. Jie, W. L. C. Loong, J. Zhang, A. G. Fane, S. Kjelleberg, et al. 2014. Characterization of Biofouling in a Lab-scale Forward Osmosis Membrane Bioreactor (FOMBR). Water Res. 58: 141151.

https://doi.org/https://doi.org/10. 1016/j.watres.2014.03.052.

[37] A. Bogler, S. Lin, E. Bar-Zeev. 2017. Biofouling of Membrane Distillation, Forward Osmosis and Pressure Retarded Osmosis:
Principles, Impacts and Future Directions. J. Memb. Sci. 542: 378-398.

https://doi.org/10.1016/j.memsci. 2017.08.001.

[38] S. Daly, E. Casey, A. J. C. Semião. 2021. Osmotic Backwashing of Forward Osmosis Membranes to Detach Adhered Bacteria and Mitigate Biofouling. J. Memb. Sci. 620: 118838.

https://doi.org/10.1016/j.memsci. 2020.118838.

[39] S. Meng, R. Wang, K. Zhang, X. Meng, W. Xue, H. Liu, et al. 2021. Transparent Exopolymer Particles (TEPs)-associated Protobiofilm: A Neglected Contributor to Biofouling During Membrane Filtration. Front. Environ. Sci. Eng. 15: 110.

https://doi.org/10.1007/s11783020-1361-7.

[40] U. Passow. 2002. Transparent Exopolymer Particles (TEP) in Aquatic Environments. Prog. Oceanogr. 55: 287-333. https://doi.org/10.1016/S00796611(02)00138-6.

[41] E. Bar-Zeev, U. Passow, S. Romero-Vargas Castrillón, $\mathrm{M}$. Elimelech. 2015. Transparent Exopolymer Particles: From Aquatic Environments and Engineered Systems to Membrane Biofouling. Environ. Sci. Technol. 49: 691-707. https://doi.org/10.1021/es50417 38.

[42] T. Berman, R. Mizrahi, C. G. Dosoretz. 2011. Transparent Exopolymer Particles (TEP): A Critical Factor in Aquatic Biofilm Initiation and Fouling on Filtration Membranes. Desalination. 276: 184-190. https://doi.org/10.1016/j.desal.2 011.03.046. 
[43] Y. Kim, S. Li, L. Chekli, Y. C. Woo, C. H. Wei, S. Phuntsho, et al. 2017. Assessing the Removal of Organic Micro-pollutants from Anaerobic Membrane Bioreactor Effluent by Fertilizer-drawn Forward Osmosis. J. Memb. Sci. 533: 8495.

https://doi.org/10.1016/j.memsci. 2017.03.027.

[44] L. Lai, L. N. Sim, W. B. Krantz, T. H. Chong. 2020. Characterization of Colloidal Fouling in Forward Osmosis Via Ultrasonic Time- (UTDR) and Frequency-domain Reflectometry (UFDR). $J$. Memb. Sci. 602: 117969. https://doi.org/10.1016/j.memsci. 2020.117969.

[45] A. N. Quay, T. Tong, S. M. Hashmi, Y. Zhou, S. Zhao, M. Elimelech. 2018. Combined Organic Fouling and Inorganic Scaling in Reverse Osmosis: Role of Protein-silica Interactions. Environ. Sci. Technol. 52: 9145-9153. https://doi.org/10.1021/acs.est.8 b02194.

[46] Y. Yu, S. Lee, S. K. Maeng. 2017. Forward Osmosis Membrane Fouling and Cleaning for Wastewater Reuse. J. Water Reuse Desalin. 7: 111120.

https://doi.org/10.2166/wrd.201 6.023 .

[47] L. Lv, J. Xu, B. Shan, C. Gao. $2017 . \quad$ Concentration Performance and Cleaning Strategy for Controlling Membrane Fouling During Forward Osmosis Concentration of Actual Oily Wastewater. $J$. Memb. Sci. 523: 15-23. https://doi.org/10.1016/j.memsci. 2016.08.058.

[48] Q. She, X. Jin, Q. Li, C. Y.
Tang. 2012. Relating Reverse and Forward Solute Diffusion to Membrane Fouling in Osmotically Driven Membrane Processes. Water Res. 46: 24782486.

https://doi.org/10.1016/j.watres. 2012.02.024.

[49] J. Liu, X. Wang, Z. Wang, Y. Lu, X. Li, Y. Ren. 2017. Integrating Microbial Fuel Cells with Anaerobic Acidification and Forward Osmosis Membrane for Enhancing BioElectricity and Water Recovery From Low-strength Wastewater. Water Res. 110: 74-82. https://doi.org/10.1016/j.watres. 2016.12.012.

[50] B. Al Hawli, A. Benamor, A. A. Hawari. 2019. A Hybrid Electro-coagulation/Forward Osmosis System for Treatment of Produced Water. Chem. Eng. Process. - Process Intensif. 143: 107621. https://doi.org/10.1016/j.cep.201 9.107621.

[51] C. F. Wan, S. Jin, T. S. Chung. 2019. Mitigation of Inorganic Fouling on Pressure Retarded Osmosis (PRO) Membranes by Coagulation Pretreatment of the Wastewater Concentrate Feed. $J$. Memb. Sci. 572: 658-667. https://doi.org/10.1016/j.memsci. 2018.11.051.

[52] T. Fujioka, M.T. Tra Ngo, T. Mochochoko, S. Boivin, N. Ohkuma, H. Yasui, et al. 2020. Biofouling Control of a Forward Osmosis Membrane During Single-Pass Pre-Concentration of Wastewater. Chemosphere. 257: 127263. https://doi.org/10.1016/j.chemos phere.2020.127263.

[53] F. Lotfi, B. Samali, D. Hagare. 2018. Cleaning Efficiency of the Fouled Forward Osmosis 
Membranes Under Different Experimental Conditions. $J$. Environ. Chem. Eng. 6: 45554563.

https://doi.org/10.1016/j.jece.20 18.06.059.

[54] J. Heo, K. H. Chu, N. Her, J. Im, Y. G. Park, J. Cho, et al. 2016. Organic Fouling and Reverse Solute Selectivity in Forward Osmosis: Role of Working Temperature and Inorganic Draw Solutions. Desalination. 389: 162-170.

https://doi.org/10.1016/j.desal.2 015.06.012.

[55] Q. She, R. Wang, A. G. Fane, C. Y. Tang. 2016. Membrane Fouling in Osmotically Driven Membrane Processes: A Review. J. Memb. Sci. 499: 201-233. https://doi.org/10.1016/j.memsci. 2015.10.040.

[56] F. Perreault, H. Jaramillo, M. Xie, M. Ude, L. D. Nghiem, M. Elimelech. 2016. Biofouling Mitigation in Forward Osmosis Using Graphene Oxide Functionalized Thin-film Composite Membranes Environ. Sci. Technol. 50: 5840-5848. https://doi.org/10.1021/acs.est.5 b06364.

[57] M. Amini, A. Rahimpour, M. Jahanshahi. 2016. Forward Osmosis Application of Modified TiO2-polyamide Thin Film Nanocomposite Membranes. Desalin. Water Treat. 57: 14013-14023. https://doi.org/10.1080/1944399 4.2015.1065441.

[58] P. S. Goh, A. F. Ismail, B. C. Ng, M. S. Abdullah. 2019. Recent Progresses of Forward Osmosis Membranes Formulation and Design for Wastewater Treatment. Water. 11: 2043. https://doi.org/10.3390/w11102
043.

[59] M. Nikbakht Fini, J. Zhu, B. Van der Bruggen, H. T. Madsen, J. Muff. 2020. Preparation, Characterization and Scaling Propensity Study of a Dopamine Incorporated $\mathrm{RO} / \mathrm{FO} \quad \mathrm{TFC}$ Membrane for Pesticide Removal. J. Memb. Sci. 612: 118458.

https://doi.org/10.1016/j.memsci. 2020.118458.

[60] W. Zhang, B. Dong. 2018. Effects of Physical and Chemical Aspects on Membrane Fouling and Cleaning Using Interfacial Free Energy Analysis in Forward Osmosis. Environ. Sci. Pollut. Res. 25: 2155521567.

https://doi.org/10.1007/s11356018-2239-0.

[61] Y. Zhao, X. Wang, Z. Wang, X. Li, Y. Ren. 2016. Nanoparticle Fouling and Its Combination with Organic Fouling During Forward Osmosis Process for Silver Nanoparticles Removal from Simulated Wastewater. Sci. Rep. 6: 1-10. https://doi.org/10.1038/srep2585 9.

[62] K. Ruengruehan, H. Kim, L. T. Hai Yen, A. Jang, W. Lee, S. Kang. 2016. Fatty Acids Fouling on Forward Osmosis Membrane: Impact of $\mathrm{pH}$. Desalin. Water Treat. 57: 75317537.

https://doi.org/10.1080/1944399 4.2015.1030118.

[63] J. Jung, J. Ryu, Y. Yu, J. Kweon. 2020. Characteristics of Organic Fouling, Reversibility by Physical Cleaning and Concentrates in Forward Osmosis Membrane Processes for Wastewater Reclamation. Chemosphere. 245: 125787. https://doi.org/10.1016/j.chemos 
phere.2019.125787.

[64] S. Lee, H. K. Shon, S. Hong. 2017. Dewatering of Activated Sludge by Forward Osmosis (FO) with Ultrasound for Fouling Control. Desalination. 421: 79-88. https://doi.org/10.1016/j.desal.2 017.02.010.

[65] L. D. Nghiem, T. Fujioka. 2016. Removal of Emerging Contaminants for Water Reuse by Membrane Technology. Elsevier B.V. 217-247. https://doi.org/10.1016/B978-0444-63312-5.00009-7.

[66] X. Wang, T. Hu, Z. Wang, X. Li, Y. Ren. 2017. Permeability Recovery of Fouled Forward
Osmosis Membranes by Chemical Cleaning During a Long-term Operation of Anaerobic Osmotic Membrane Bioreactors Treating Lowstrength Wastewater. Water Res. 123: 505-512. https://doi.org/10.1016/j.watres. 2017.07.011.

[67] X. Liu, J. Wu, L. an Hou, J. Wang. 2020. Fouling and Cleaning Protocols for Forward Osmosis Membrane Used for Radioactive Wastewater Treatment. Nucl. Eng. Technol. 52: 581-588. https://doi.org/10.1016/j.net.201 9.08.007. 